\title{
Cosmopolitanism and Classical Sociology
}

\author{
Inglis, David
}

Brill

2020-12-17

Inglis , D 2020 , Cosmopolitanism and Classical Sociology . in V Cicchelli \& S Mesure (eds), Cosmopolitanism in Hard Times . , 3 , International Studies in Sociology and Social pÿAnthropology , Brill , Leiden , pp. 5366 . https://doi.org/10.1163/9789004438026_005

http://hdl.handle.net/10138/338915

https://doi.org/10.1163/9789004438026_005

cc_by_nd

acceptedVersion

Downloaded from Helda, University of Helsinki institutional repository.

This is an electronic reprint of the original article.

This reprint may differ from the original in pagination and typographic detail.

Please cite the original version. 


\section{Chapter 3}

\section{Cosmopolitanism and Classical Sociology}

David INGLIS

\section{Introduction}

This chapter sets out the main relationships between the body of knowledge customarily referred to as 'classical sociology' and ideas about cosmopolitanism. Cosmopolitan currents run throughout the works of the major classical sociologists. One such current is primarily to be found among German classical sociologists, while another is discernible among French thinkers.

The chapter traces these developments in the thought of Marx and Tönnies on the one side, and Saint-Simon, Comte, and Durkheim on the other. Both currents in large part come out of the cosmopolitan thinking of Immanuel Kant. ${ }^{1}$ The German focus was more on the ambivalently cosmopolitan nature of capitalism, especially embodied in the metropolis. The French focus was more on intergroup solidarities and the emergence of transnational moral cultures. Both foci can be said to be still relevant for understanding cosmopolitanism and globalization processes today.

\section{Irrelevant classics?}

What are we today to make of the classical sociologists' cosmopolitan thinking? One possible answer is that all the major thinkers were insufficiently cosmopolitan, being far too rooted in nation-state-centric ways of thinking. In the early 2000s, Ulrich Beck (2002) set out the epistemological contours of a contemporary 'cosmopolitan sociology' able to grasp the

\footnotetext{
${ }^{1}$ See Chapter 2 in this volume.
} 
complexities of transnational, globalizing processes. He contrasted this with the classical sociologists' alleged methodological nationalism. In the 19th century:

the association between sociology and nation-state was so extensive that the image of 'modern,' organized individual societies — which became definitive with the national model of political organizationitself became an absolutely necessary concept in and through the founding work of classical social scientists. Beyond all their differences, such theorists as Émile Durkheim, Max Weber and even Karl Marx shared a territorial definition of modern society, and thus a model of society centered on the national-state, which has today been shaken by globality and globalization. (Beck, 2000: 24)</EXT>

This viewpoint has met with much criticism since the late 1990s. Some scholars (Chernilo, 2006, 2007) have found the place of the nation-state in classical sociological thinking to be much more ambivalent than Beck alleged. The ideas of the classical sociologists tended to reflect and refract not only the territorial structures of nation-states, but also the emerging transnational contexts. While Marx sometimes emphasized the power of particular nationstate governments over the workers' movement, his analysis of that transnational movement, and of the globalizing capitalism that was its antagonist, very much emphasized the planetwide spread of both. Chernilo (2006, 2007) likewise acquits Max Weber of the charge of methodological nationalism, as Weber did not define the term 'society' in a national sense, nor did he focus on social relations which only operated within states' borders.

Much classical sociology, especially its Durkheimian variant, has been defended as possessing cosmopolitan visions which Turner (2006: 133; also 1990) argues were intended 
'to challenge the nationalist assumptions' of the times (Fine, 2003a, 2003b). While Beck would exempt classical sociologists from the conceptual realm of contemporary cosmopolitan sociology, the scholars mentioned want to include them. The classical thinkers seem much more attuned to the emergence of cosmopolitan and globalizing phenomena in their own times than Beck admitted. Because at least some classical thinkers were much more sensitive to world-spanning complexification processes than Beck's account allowed for, they may still be of use today for thinking in cosmopolitan ways about real-world 'cosmopolitizing' processes.

\section{Back to Kant}

One ironic feature of Beck's attack on the classical sociologists for being insufficiently cosmopolitan is that both the thinkers he criticized and his version of cosmopolitan sociology are very much indebted to the thought of Immanuel Kant. Thinkers in 19th-century France and Germany took up Kant's legacy in differing ways. So too did Beck-so much so that some of his critics have alleged that his vision of a cosmopolitan world in our own times is insufficiently empirically grounded, in fact being a disguised Kantian political philosophy (Roudometof, 2005).

Beck seems not to have appreciated that some of the classical sociologists were also doing precisely what he was trying to do: to recalibrate Kantian cosmopolitan thinking for new times, and to develop a workable cosmopolitan sociology-or sociology of empirical cosmopolitan conditions-partly out of Kant's cosmopolitanism. Kant's cosmopolitan thinking has been the focus of much attention since the late 1990s, stimulated by Nussbaum's (1997) attempt to revivify it. Critics have also pointed to Kant's alleged racism, which seems to undermine his claim he was a truly cosmopolitan thinker (Papastephanou, 2002). 
Nonetheless, Kant's cosmopolitanism was never located only in the realm of political philosophy, for it was also already a kind of sociology, aimed at understanding emergent empirical cosmopolitan conditions across the world (Inglis, 2014). Kant's analysis seeks to discern the emergence of cosmopolitan political and moral structures that come to affect every part of the world, and to understand the empirical global historical processes that have made these possible. Kant's writings encompass both a set of world-encompassing cosmopolitan norms and actually existing political structures, as well as empirical processes - that today we might call 'globalization' - which make possible and spread those structures and norms across the world.

Kant tells a very long-term historical story in this regard. Initial human dispersal across the habitable parts of the planet was followed by increasing interconnections among geographically disparate groups. By placing 'each people near another which presses upon it,' historical conditions compelled each group to 'form itself into a state in order to defend itself.' This provoked wars between states. Two cultural factors also impelled different states to be hostile to each other: 'differences of language and of religion ... involve a tendency to mutual hatred and pretexts for war' (Kant, 1963a: 111). It was the human propensity to discord which paradoxically eventually drove humans to peaceful forms of association, first within particular states (the social contract à la Hobbes and Locke), and then between states (i.e., cosmopolitan world conditions). Humans in the very long run learnt that the best means of meeting their interests, individual and collective, was to engage in peaceful 'national' and 'inter-national' association with each other. World history eventually brought about, among humans,

$<$ EXT $>$ that which reason could have told them at the beginning and with far less sad experience ... to step from the lawless condition of 
savages into a league of nations ... [where] even the smallest state could expect security and justice ... a united power acting according to decisions reached under the laws of their united will. (Kant, 1963b: 19) $\langle/ \mathrm{EXT}>$

This is a 'cosmopolitan condition' that eventually will pertain throughout the whole world (Kant, 1963b: 20).

Kant adds that over time intergroup trade develops. Different states 'unite because of mutual interest. The spirit of commerce, which is incompatible with war, sooner or later gains the upper hand in every state ... states see themselves forced, without any moral urge, to promote honourable peace' (1963a: 114). Increasingly, world-level trading relations help to create 'understanding, conventions and peaceable relations [which are] established [even] among the most distant peoples' (1963a: 110). Kant's emphasis on the potentially peacegenerating effects of world-level trade was a reflection of broader 18th-century liberal and radical sentiments, to be found in the work of figures like Adam Smith and Voltaire (Muller, 2003).

Kant discerned only the beginnings of a world-level cosmopolitan order in his own period. But he was confident that the current situation showed that 'there is a rising feeling which each [state] has for the preservation of the whole ... [and thus] a universal cosmopolitan condition ... will come into being' at some point (1963b: 23). He also discerned the first flourishing of a world-level moral community. Within this 'a violation of rights in [any] one place is felt throughout the world' (1963a: 105; emphasis added). This is an important early anticipation of later notions of a world-spanning moral culture, based around sentiments of revulsion for, and condemnation of, actions which undermine human rights. Regardless of where those actions might happen, the condemnation that follows is 
literally global: it comes from all over the world, and in effect is the moral response of the whole world, understood as a single moral entity (1963a: 103).

This view of the really existing nature of a global moral culture furnished Kant with the grounds to strongly criticize colonizing European states which had gone to 'terrifying lengths' to subjugate other peoples, stealing their lands from them (1963a: 103). If colonialism is a facet of globalization, so too is the very globe-spanning moral culture that provides grounds for colonialism's condemnation. Globalization simultaneously produces both colonialism, as well as the moral norms and means (e.g., newspapers of global reach) for condemning it.

\section{The cosmopolitan features of capitalism and Gesellschaft}

In these reflections by Kant, one can see the beginnings of the dialectical accounts of world history in general, and of empirical globalization processes that would later be taken up by Hegel and then Marx (Buchwalter, 2011). Marx's views on the worldwide spread of capitalism, out from Europe to the rest of the world, betray the influence of Kant's account of cosmopolitan historical unfolding.

In the Communist Manifesto, Marx and Engels (1968 [1848]: 38) argued that 'the need of a constantly expanding market for its products chases the bourgeoisie over the whole surface of the globe.' Capitalism's dynamic nature compels it, in the constant search for profit, to expand its markets across the world. The capitalist class seeks to bring every single person on the planet under its sway, as both an exploited producer of goods and as a consumer of them. Increasingly, globe-spanning capitalism 'batters down all Chinese walls ... It compels all nations, on pain of extinction, to adopt the bourgeois mode of production ... [and] to introduce what it calls civilization into their midst, i.e., to become bourgeois themselves' (Marx and Engels, 1968 [1848]: 38). 
Marx thought that all regions of the world would eventually be thoroughly transformed by capitalism, local cultures being swept away by a new world-encompassing order of production, profit, and exploitation. This socioeconomic set of affairs is understood by Marx as being quite as 'cosmopolitan' as the socio-moral cultural world condition envisaged by Kant. Marx's famous ambivalence about capitalism is clear in this regard. The development of European colonial expansion is recognized as bloody and vicious, but the arrival of Europeans in places like India is seen to pave the way for a global socialist revolution. Colonialism smashes older and more local structures of ruling-class power and ideology, creating the conditions for modernized industry and economic relations, and thus a new globe-spanning proletariat. Consequently, Marx has been criticized for his acceptance of the destruction of local cultures around the world, in the name of blindly Eurocentric notions of 'progress' (Howe, 2007).

Marx's influence — and more dimly that of Kant — can also be discerned in the ideas of another important German classical sociologist, Ferdinand Tönnies. Tönnies (1957 [1887]) introduced to sociology the famous distinction between Gemeinschaft and Gesellschaft. This describes a movement from situations where tightly bound, affectively based groups were the main sorts of social actors, to those where rationally calculating, selfish individuals occupied center-stage in the social order. One might also examine a particular society and possibly find within it elements both of Gemeinschaft and of Gesellschaft. Tönnies explicitly defines the Gesellschaft created by the merchants as 'modern, cultured, cosmopolitan,' for reasons explicated below (ibid.: 134). These concepts are derived from two more fundamental notions, two different types of 'will' - that is, the ways in which an individual conceptualizes the world and acts upon it. These are Wesenwille (natural will) and Kürwille (rational will). The former involves a judgment as to the intrinsic value of an act rather than its practicality. The latter involves a conscious choice of specific means for the pursuit of a specific end. 
While Wesenwille - characterized by strong affectivity and group-oriented feelingsdescribes the typical psychological and social-relational dispositions that constitute Gemeinschaft, Kürwille describes dispositions-involving high levels of individualistic calculation-that constitute Gesellschaft.

An important rejoinder to Beck's criticism of classical sociology is that for Tönnies (a thinker whom Beck did not explicitly mention), neither Gemeinschaft nor Gesellschaft is seen to be contained within nation-state borders. One could apply this mode of analysis to any configuration of social relations, including transnational ones. There is no reason why Gemeinschaft or Gesellschaft, or Wesenwille and Kürwille, have to refer to 'national' entities. Tönnies was not methodologically nationalist, but rather provided categories that could be used for cosmopolitan sociological purposes. Indeed, Tönnies explicitly states that 'the existence of ... [nation-]states is but a temporary limitation of the boundaryless Gesellschaff' (Tönnies (1957 [1887]: 221).

For Tönnies, the innate tendency of Kürwille forms of consciousness is to pull ever greater numbers of people into their orbit, such ways of thinking having a decontextualized character which allows them to spread anywhere and everywhere. The group that above all promotes these ways of thinking are the class of merchants, who for Tönnies are the real cosmopolitan revolutionaries of human history. Gesellschaft is defined by Tönnies (1957 [1887]: 76) as 'a condition in which, according to the expression of Adam Smith, 'Every man ... becomes in some measure a merchant.' The merchant class's embodiment of the spirit of Kürwille, as well as their capacity to transmit over large distances its characteristic modes of thought and interaction, give them a powerful capacity to transform social relations wherever their reach is felt. Tönnies approvingly cites Adam Smith: 'A merchant ... is not necessarily the citizen of any particular country' (ibid.: 81). The merchant is radically cosmopolitan because 


\begin{abstract}
$<$ EXT $>$ [he or she] is without home, a traveller, a connoisseur of foreign customs and arts without love or piety for those of any one country, a linguist speaking several languages. Flippant and doubletongued, adroit, adaptable ... [S]he moves about quickly and smoothly, changes his [or her] character and intellectual attitude (beliefs or opinions) as if they were fashions of dress, one to be worn here, another there. (Tönnies, 1957 [1887]: 168)</EXT>
\end{abstract}

The merchant's exceptional freedom from the thought patterns of Wesenwille, and the social relations of Gemeinschaft, means that he is unburdened by any of the moral considerations of Gemeinschaft, such as ties of patriotism. While the home-loving peasant 'turns his [or her] attention inwardly towards the centre of the locality ... to which $[\mathrm{s}]$ he belongs $\ldots$ the trading class lends its attention to the outside world; it is concerned only with the roads which connect towns and with the means of transit' (Tönnies, 1957 [1887]: 79).

Tönnies develops Marx's ideas by saying that the purest expressions of Kürwille forms of consciousness and Gesellschaft modes of action and interaction are capitalist forms of exchange and production. These are 'cosmopolitan and [potentially] unlimited in size' (Tönnies, 1957 [1887]: 258-259). The merchants' capitalist ways of thinking and acting reach out from the urban areas where they were originally concentrated, pulling ever more locales into their sphere of influence:

$<E X T>$ The more extensive the trade area, the more probable it is that the pure laws of exchange trade prevail, and that those other noncommercial qualities which relate men [sic] and things may be 
ignored. Trade tends, finally, to concentrate on one main market, the world market, upon which all other markets become dependent. (Tönnies, 1957 [1887]: 79)</EXT>

Just as Gemeinschaft is by definition about locality, Gesellschaft, its ideal-typical opposite, is by definition non-local (indeed anti-local) and always potentially global in scope. Kürwille involves modes of formal rationality that could be adopted anywhere and everywhere, precisely because they are not freighted with the weight of cultural particularities. The generalizability, transportability, and mobility of Kürwille is what makes this way of thinking always potentially global in reach and therefore profoundly cosmopolitan in nature (Ritzer, 2007).

The cosmopolitan nature of the urban metropolis is central in Tönnies' thinking. The 'more general the condition of Gesellschaft becomes in the nation or a group of nations, the more this entire "country" or the entire "world" begins to resemble one large city' (ibid.: 227). Each particular metropolis, like Berlin or New York, is described thus:

$<$ EXT $>$ [It contains] representatives from a whole group of nations, i.e. of the [whole] world. In the metropolis, money and capital are unlimited and almighty. It is able to produce and supply goods and science for the entire earth as well as laws and public opinion for all nations. It represents the world market and world traffic; [and] world industries are concentrated. Its newspapers are world papers, its people come from all corners of the earth, being curious and hungry for money and pleasure. (Tönnies, 1957 [1887]: 266-267)</EXT> 
Echoing Kant's points about the emergence of global public opinion through the emergence of transnational media, the metropolis has media outlets that are 'not confined within natural [sic] borders, but, in its tendencies and potentialities,... [are] definitely international' (Tönnies, 1957 [1887]: 221).

The Gesellschaft of the metropolis is also 'pervaded with haste, unrest, continual novelty, fluidity and a persistence only in incessant change' (Tönnies, 1957 [1887]: 135). These are themes that Marx had already pointed to about incessant change in the big cities of the capitalist world system. Such ideas were also taken up by Georg Simmel. Tönnies argues that in the huge urban agglomerations, 'the arts must make a living; they are exploited in a capitalistic way. Thoughts spread and change with astonishing rapidity. Speeches and books through mass distribution become stimuli of far-reaching importance' (ibid.: 227-228). Novel ideas, opinions, and styles are created, and are at first taken up by metropolitan elites. '[T]he views of the upper and ruling classes ... are formed outside of custom ... These views partially originate in deviant new usages and habits, and the latter are frequently based on an imitation of strangers' and foreigners more generally (Tönnies, 1961 [1909]: 114). Ideas and realities are therefore constantly being cosmopolitized. Through a series of what are nowadays called 'inventions of tradition' (Hobsbawm and Ranger, 1992), metropolitan elites try to construct forms of culture that are allegedly expressive of older forms of Gemeinschaft. The lower-middle and working classes eventually take up cultural forms, both (supposedly) native and more (explicitly) cosmopolitan, imported or invented by their social superiors (Tönnies, 1961 [1909]: 117). Over time, even the lowest social classes thus come to exist within increasingly cosmopolitized social realities. Tönnies' striking thoughts about the cosmopolitization of sociocultural conditions were, alas, almost completely ignored in Beck's critique of classical sociology. 


\section{$<$ H1 $>$ Cosmopolitan thematics in French sociology}

Just as Kant's cosmopolitan themes were taken up and developed in a German line of thought about capitalism and metropolises, so too were they adapted by thinkers in the French sociological tradition, most notably Durkheim. The latter's cosmopolitan sociology mediated the Kantian inheritance through France's distinctive intellectual and political culture.

Utopian socialism was an important influence on embryonic sociology in France. With an echo of Kant's optimism, Saint-Simon and his followers argued that the end point of human history was 'universal association ... the association of all men $[\mathrm{sic}]$ on the entire surface of the globe in all spheres of their relationships' (Iggers, 1958: 58). The ancient Greek cosmopolitan idea of universal brotherhood was recalibrated to become a product of the emerging global division of labor. Over time, 'the various nations, scattered over the face of the earth, shall appear only as members of one vast workshop, working under a common law for the accomplishment of one and the same destiny' (ibid.: 85). Similar sentiments were voiced by Auguste Comte. The likelihood of 'universal peace' is increased as 'labor becomes an instrument for humanity as a whole' (Boas, 1928: 151-152). What Durkheim would later call 'organic solidarity' was envisaged by Saint-Simon, Comte, and others as being both a cosmopolitan (world-spanning) phenomenon, and having cosmopolitan moral-political outcomes.

Durkheim's cosmopolitanism synthesizes Saint-Simonian and Comtean with Kantian themes. The political philosophy Durkheim adumbrated at the turn of the 20th century was clearly an attempt to update Kantian themes for new times. Turner (2006: 141) notes that 'in equating what he called "true patriotism" with cosmopolitanism, Durkheim anticipated the modern debate about republicanism, patriotism and cosmopolitanism by almost a century.' Durkheim sought to reconcile nation-state structures and national identities with 
cosmopolitan moral dispositions, in a like manner to present-day thinkers such as Appiah (1996). These themes were set out at the Paris Universal Exposition of 1900:

$<$ EXT $>$ Doubtless, we have towards the country in its present form, and of which we in fact form part, obligations that we do not have the right to cast off. But beyond this country, there is another in the process of formation, enveloping our national country: that of Europe, or humanity. (Cited in Lukes, 1973: 350)</EXT>

Durkheim formulated these ideas further in lectures on morality and politics he gave in Bordeaux between 1890 and 1900, repeated at the Sorbonne in 1904 and 1912 (Durkheim, 1992). Durkheim here considered the apparently contradictory notion of 'world patriotism.' This does not involve modes of affiliation to a putative 'world state.' Like Kant, he notes that 'such an idea, while not altogether beyond realization, must be set in so distant a future that we can leave it out of our present reckoning' (Durkheim, 1992: 74).

He then develops the concept of 'world patriotism' from within what he takes to be the apparently rigid empirical realities of the contemporary international system, while attempting to raise this system to what he understands as a higher moral and ethical level, very much mirroring Kant's earlier efforts. Each state should, and in future would, encourage the highest moral sentiments among all its citizens. Each national government would endeavor 'not to expand, or to lengthen its borders, but to set its own house in order and to make the widest appeal to its members for a moral life on an ever higher level' (Durkheim, 1992: 74). If this were to happen, then 'civic duties would be only a particular form of the general obligations of humanity' (ibid.). 
Durkheim here points toward some kind of 'world culture,' constituted of certain moral and ethical codes, which are contributed to by particular nation-states. When these codes have become part of an acknowledged 'world culture,' they are in turn taken on board by all of nation-states, albeit with specific national colorings, regarding the education of the actions and aspirations of the citizenry. Durkheim notes that the various European countries 'have not yet reached the point when this kind of patriotism could prevail without dissent' (Durkheim, 1992: 75). But Durkheim, again like Kant, wishes to root his cosmopolitical philosophy in an account of what he takes to be emerging world-level social conditions that could further foster the desired political outcome of cosmopolitan forms of citizenship.

Turner (1990: 347) has argued that for obvious pragmatic reasons compelled by the international political situation, at the outbreak of the First World War Durkheim partly turned away from such explicitly cosmopolitan reflections toward 'the idea of nationalism as a modern version of more traditional sources of the conscience collective.' This is partly true, but we must add that the onset of war did not see Durkheim relinquishing the cosmopolitan 'world patriotism' position entirely. Indeed, his cosmopolitan political position was repurposed as a crucial resource for dealing with challenging wartime conditions.

In the 1915 pamphlet entitled 'Germany Above All,' Durkheim shows the German state's aggressive behavior is driven by a narrow and chauvinistic nationalism that is antithetical to 'world patriotism.' It is morally condemnable because it goes against the norms of - the empirically existing, if rudimentary, contemporary version of-world patriotism and world moral culture. German elites of the 19th century were positive contributors to 'world culture,' as they were people 'who belonged without any reservation to the same moral community as we ourselves' in France and the Allied countries (Durkheim, 1915: 4). But the Germans' instigation of the war and their brutal treatment of both combatants and civilians alike signified a total denial of their moral responsibilities as members of the global 'moral 
community.' Germany had become a rogue state, far removed from the norms of world-level moral culture. Germany could be forcefully condemned on the basis of existing world-level norms, precisely because it had flouted these so flagrantly.

For Durkheim to be able to make a convincing case about the existence of such a world moral culture, he had to demonstrate the mechanisms whereby such a culture had come into existence, moving, like Kant, from the more abstract realm of political philosophy to the more concrete world of history and social conditions. This is exactly what The Elementary Forms of the Religious Life (Durkheim, 2001 [1912]) partly set out to achieve. An embryonic theory of globalization is contained in its later chapters, which underpins his views on world moral culture and political cosmopolitanism (Inglis and Robertson, 2008).

These later chapters depart quite considerably from the strong emphasis on 'society' understood as a bounded, territorial unit, with strong symbolic boundaries surrounding it, found in the earlier chapters. What comes into sight at the book's end is an account of the sociological reasons whereby a world-spanning moral culture develops over time. Australian aboriginal ethnographic material is deployed to demonstrate that 'religious universalism' - a condition whereby a particular belief system claims to have authority over, and relevance for, more than one social group — is found not just in the 'world religions' but 'at the summit' of Australian aboriginal religion too. Durkheim argues that in Australia, particular gods are recognized by multiple tribes, and so 'their cult is, in a sense, international' (2001 [1912]: $321)$.

Echoing Kant's points about human dispersal across the planet, neighboring tribes are seen to be unable, over the long term, to avoid contact with each other, and progressively they become more systematically interlinked, primarily through the means of trade and group intermarriage. They enter into conditions whereby they become ever more conscious of what aspects of life they have in common, and 'mutual [cultural] borrowings ... serve to reinforce' 
this sense of 'international' commonality (Durkheim, 2001 [1912]: 321). With the increasing interpenetration of previously distinct tribal groups at the material level (a basic form of emergent organic solidarity), 'international gods' are born. Each tribe's idea of a god fuses with the ideas of the other tribes with whom they are in systematic contact. The resulting 'international god' is made manifest as an idea in the minds of all participants. The 'international gods' are therefore products of a 'hybridization' of distinct tribal (or in more modern terms, 'national') traditions.

The 'international gods' are, for Durkheim, above all gods of initiation ceremonies. As such, they are generated through the initiation rituals held at 'intertribal assemblies.' Durkheim argues that at these assemblies 'sacred beings were ... formed that were not fixed to any geographically fixed society.' The geography they correspond to, and in fact are produced by, is intertribal, that is to say 'inter-national' or 'inter-societal.' It does not have clear borders, and conceptually speaking is 'spread over an unlimited area.' The gods that correspond to this territory 'have the same character [as the territory itself]; their sphere of influence is not circumscribed; they glide above the particular tribes and above space. They are the great international gods' (Durkheim, 2001 [1912]: 321).

A territorially bounded 'society' produces a body of religious beliefs which express the structure of that society. We might therefore expect that 'international' or 'global' society produces a body of beliefs_-about, and symbolized by, 'international gods' — which reflect its nature too. If 'national' religions are the necessary preconditions for effective social functioning within a given bounded 'society,' then the functioning of an international or global society would also seem to depend on its 'religious' expressions, both in the guiding of individuals' actions through norms and in the carving up of 'reality' through its cognitive lenses. An 'international' or 'global' religion does its conceptual carving up of reality in ways 
that are more 'cosmopolitan' than those of 'national' religions, especially given that the former is a hybrid and emergent entity.

Using these ideas about aboriginal international religion, Durkheim sought to analyze the emerging world-spanning social and cultural conditions of his day. He notes that in the present day,

\footnotetext{
$<$ EXT $>$ there is no people, no state, that is not involved with another society that is more or less unlimited and includes all peoples ... There is no national life that is not dominated by an inherently international collective life. As we go forward in history, these international groupings take on greater importance and scope ...' (2001 [1912]: 322)</EXT>
}

The globalizing transformation of aboriginal life in the past revealed the essential mechanisms of growing organic solidarity, intergroup assembly, and cultural hybridization that have previously generated cosmopolitan moral cultures. For Durkheim, similar mechanisms are again producing the latter, in his present and in the future, but this time at a truly global level.

\section{Conclusion}

This chapter has examined two major lines of cosmopolitan thinking and politics in classical sociology, one which developed among German thinkers and another which was elaborated by French scholars. Both streams of thought derive from Kant's original formulations, and then were adapted to different national intellectual contexts and changing empirical conditions. Each stream of thought emphasizes a different articulation of cosmopolitanism 
and sociology, the German trend focusing more on capitalism and the metropolis, the French tradition more oriented to issues of culture, morality, and the civil sphere.

The blind spots of the one tradition can be partly overcome by consideration of the insights of the other. For example, the sometimes more harsh and pessimistic tenor of the Germanic version can be compensated for by the more optimistic and positive French dispositions, and vice versa. Putting both strands together indicates an overall trajectory in 19th- and early 20th-century European sociological thought which engaged, problematically but still fruitfully, with multiple issues to do with cosmopolitanism, nationalism, intergroup relations, and morality in a globalizing world context. The classical sociologists covered much of the same social, political, and moral terrain with which cosmopolitan sociologists nowadays seek to deal. Their analytic orientations are, despite their flaws, still worth attending to.

\section{References}

Appiah, A. 1996. 'Cosmopolitan Patriots.' In For Love of Country: Debating the Limits of Patriotism, edited by J. Cohen, 21-29. Cambridge, MA: Beacon.

Beck, U. 2000. What Is Globalization? Cambridge, UK: Polity Press.

Beck, U. 2002. 'The Cosmopolitan Society and Its Enemies.' Theory, Culture and Society 19 (1-2): $17-44$.

Boas, F. 1928. Anthropology in Modern Life. New York: Norton.

Buchwalter, A. (ed.). 2011. Hegel and Global Justice. Amsterdam: Springer.

Chernilo, D. 2006. 'Social Theory's Methodological Nationalism: Myth and Reality.' European Journal of Social Theory 9 (5): 5-22.

Chernilo, D. 2007. 'A Quest for Universalism: Re-assessing the Nature of Classical Social Theory's Cosmopolitanism.' European Journal of Social Theory 10 (1): 17-35. 
Durkheim, É. 1915. 'Germany Above All: German Mentality and War.' Librairie Armand Colin, Paris.

Durkheim, É. 1992. Professional Ethics and Civic Morals. London: Routledge.

Durkheim, É. 2001 [1912]. The Elementary Forms of Religious Life. Oxford: Oxford University Press.

Fine, R. 2003a. 'Kant's Theory of Cosmopolitanism and Hegel's Critique.' Philosophy and Social Criticism 29 (6): 609-630.

Fine, R. 2003b. 'Taking the "Ism" Out of Cosmopolitanism: An Essay in Reconstruction.' European Journal of Social Theory 6 (4): 451-470.

Hobsbawm, E. and T. Ranger (eds.). 1992. The Invention of Tradition. Cambridge, UK: Cambridge University Press.

Howe, S. 2007. 'Edward Said and Marxism: Anxieties of Influence.' Cultural Critique 67: $50-87$.

Iggers, G. 1958. The Doctrine of Saint-Simon: An Exposition. Boston, MA: Beacon.

Inglis, D. 2009. 'Cosmopolitan Sociology and the Classical Canon: Ferdinand Tönnies and the Emergence of Global Gesellschaft.' British Journal of Sociology 96 (12): 813-832.

Inglis, D. 2014. 'Cosmopolitanism's Sociology and Sociology's Cosmopolitanism: Retelling the History of Cosmopolitan Theory from Stoicism to Durkheim and Beyond.' Distinktion: Scandinavian Journal of Social Theory 15 (1): 69-87.

Inglis, D. and R. Robertson. 2008. 'The Elementary Forms of Globality: Durkheim and the Emergence and Nature of Global Life.' Journal of Classical Sociology 8 (1): 5-25.

Kant, I. 1963a. 'Idea for a Universal History from a Cosmopolitan Point of View.' In On History, edited by L. White Beck. Indianapolis: Bobbs-Merrill. 
Kant, I. 1963b. 'Perpetual Peace.' In On History, edited by L. White Beck. Indianapolis: Bobbs-Merrill.

Lukes, S. 1973. Emile Durkheim: His Life and Work. A Historical and Critical Survey. London: Allen Lane.

Marx, K. and F. Engels. 1968 [1848]. 'Manifesto of the Communist Party.' In Marx-Engels Selected Works. Moscow: Progress Publishers.

Muller, J. 2003. The Mind and the Market. New York: Anchor.

Nussbaum, M. 1997. 'Kant and Stoic Cosmopolitanism.' Journal of Political Philosophy 5 (1): $1-25$.

Papastephanou, M. 2002. 'Kant's Cosmopolitanism and Human History.' History of the Human Sciences 15 (1): 17-37.

Renton, D. 2001. Marx on Globalization. London: Verso.

Ritzer, G. 2007. The Globalization of Nothing. Newbury Park, CA: Pine Forge.

Roudometof, V. 2005. 'Transnationalism, Cosmopolitanism and Glocalization.' Current Sociology 53 (1): 113-115.

Tönnies, F. 1957 [1887]. Community and Society, edited and translated by C. D. Loomis. London: Routledge.

Tönnies, F. 1961 [1909]. Custom: An Essay on Social Codes. New York: Free Press.

Turner, B. S. 1990. 'The Two Faces of Sociology: Global or National.' Theory, Culture \& Society 7 (3-4): 317-332.

Turner, B. S. 2006. 'Classical Sociology and Cosmopolitanism: A Critical Defence of the Social.' British Journal of Sociology 57 (1): 133-151. 